\title{
Protection for Birds of Prey Urged
}

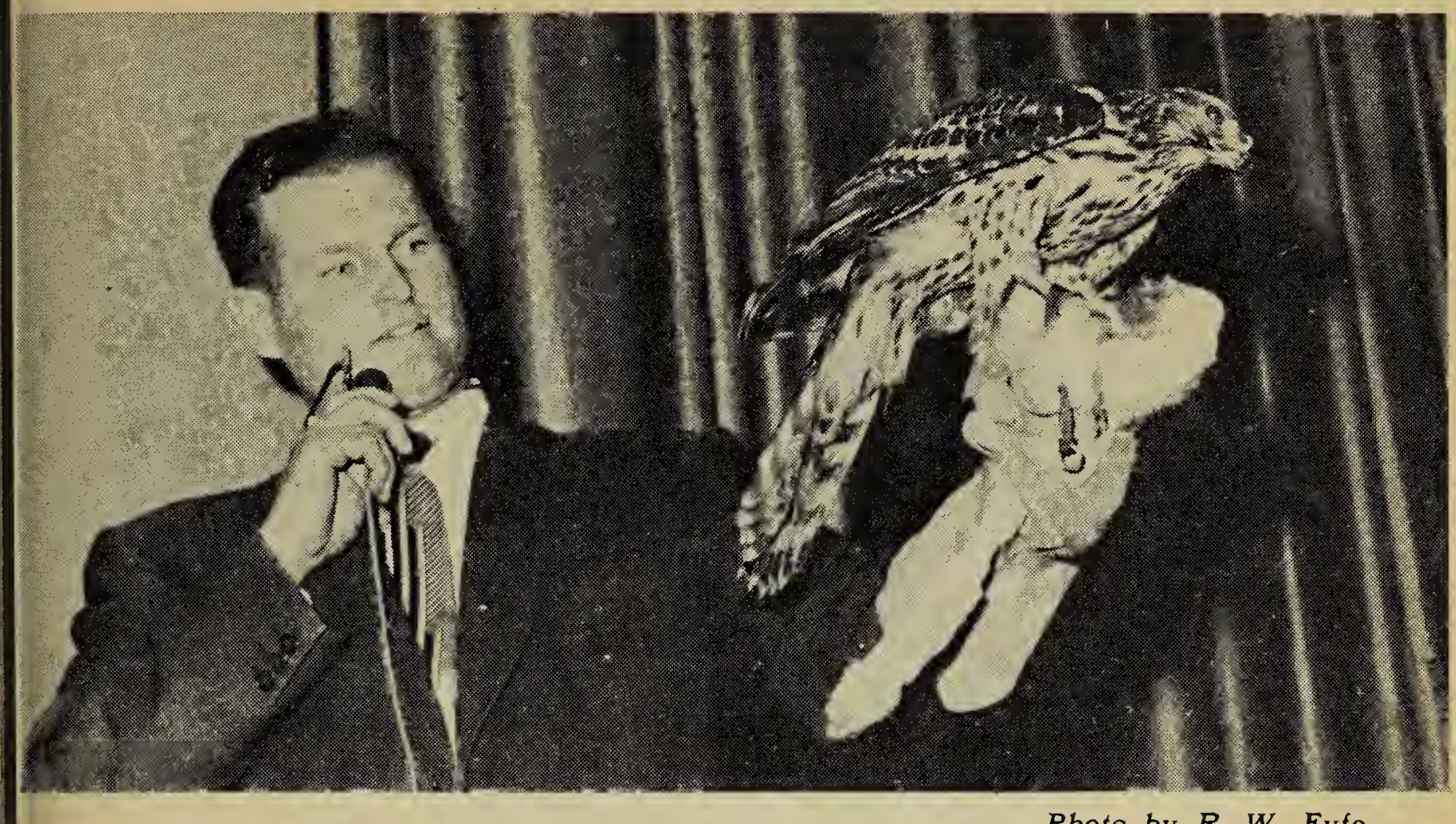

Photo by R.W. Fyfe

AL OEMING WITH GOSHAWK AT REGINA MEETING, MARCH 20. 1958

An especially interesting meeting of the Regina Natural History Society on March 20, 1958, brought together two Canadian naturalists who are actively concerned about protection for birds of prey-Al Oeming, President of the Edmonton Zoological Society, and John A. Livingston, Executive Director of the Audubon Society of Canada, who came from Toronto for the meeting. A large audience heard the special talk given by Al Oeming on the value of birds of prey and the necessity for protecting them by legislation. Support was riven the guest speaker's plea for protection for birds of prey by John A. Livingston who spoke for the Audubon Society of Canada and reviewed the progress that has already peen made in Canada toward achievng such protective legislation. Both Mr. Oeming and Mr. Livingston urged hat Saskatchewan revise its present aws in order to give protection to ts birds of prey which are particuarly vulnerable on the open plains. The meeting then passed a motion hat the society urge such protective legislation and that the president pame a committee to study the quesion and prepare a resolution for resentation to the government. This ommittee was empowered to contact ther clubs in Saskatchewan, includng such groups as natural history ocieties and fish and game leagues.
Because we know that Blue Jay. readers are interested in questions of conservation, we are summarizing the arguments advanced in support of protection of the birds of prey by Al Oeming and John Livingston.

In addition to explaining the role of the birds of prey, Mr. Oeming told of study and conservation projects in which he himself has been active, such as his province-wide canvass of information on the Great Gray Owl and his study of the habits and movements of the Snowy Owl. He dwelt on the magnificent physical attributes of the birds of prey, as well as their function in the natural order. "When you kill one of these beautiful birds," he said, "you suffer two losses-a spiritual one and an economical one.',

In a country as large as ours, Mr. Oeming pointed out, there is certainly room for all forms of wildlife. "We are living in an age that is growing increasingly complex, and we actually hunger for closer associations with nature. If we deal with these problems intelligently and objectively, we can have our agricultural areas, we can continue to expand our industrial developments, and at the same time we will be able to perpetuate and enjoy a healthy and fully representative wildlife population." 


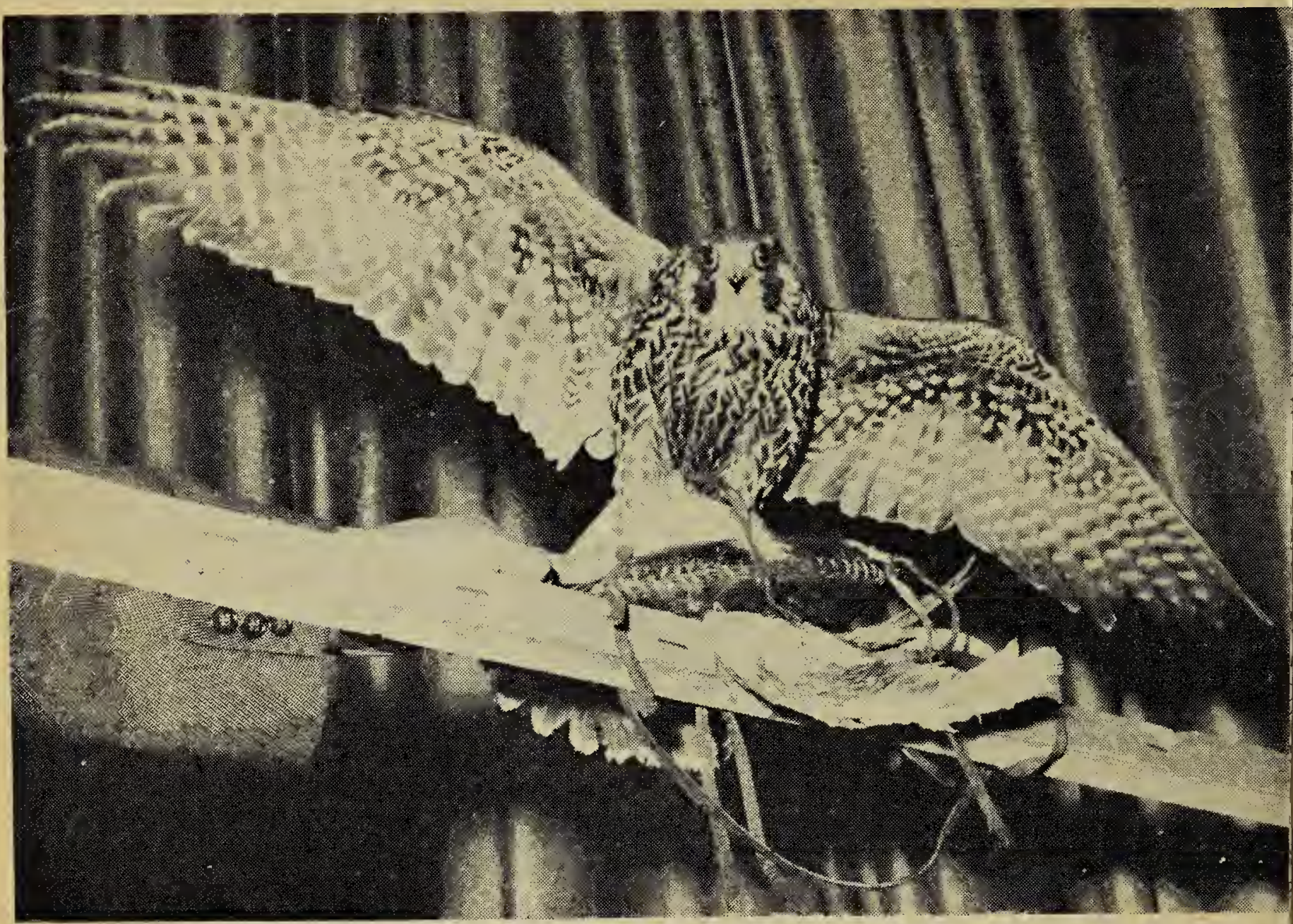

Photo by R. W. Fyte

PEREGRINE FALCON BROUGHT TO REGINA MEETING BY AL OEMING

In an open letter to the editor of the Blue Jay, John A. Livingston defined the position of the Audubon Society of Canada in regard to the question of securing legal protection for birds of prey. In several provinces in Canada, the Audubon Society has given active support to groups working for this protective legislation. The following arguments are the basis of its campaign.

Hawks and owls of many species are extremely important to agriculture because they control rodents. Because such hawks as the buteos are known to be beneficial in this regard, partial protection of birds of prey is often urged. But partial protection is not an intelligent conservation practice for several reasons. In the first place, the average person cannot distinguish between one species of hawk and owl and another. In practice, therefore, partial protection does not protect the hawks and owls it is designated to protect.

In the second place, all hawks and owls have a useful natural function. Predators are known today to be a vitally important part of the wildlife community. Predation is one of the controls exercised over all things living in the wild. Under natur: conditions, the bird-eating raptor (e.g. Goshawk and Peregrine) cer tainly do take birds. But even i taking birds they perform a positiv useful function. They take the birc most easily caught, in many case the weaker individuals, helping 1 guarantee a vigorous breeding popu lation. In this way, they contribut to the intelligent cropping of surpli populations. No form of animal lit can increase beyond the capacity the environment to supply food for i Surplus populations would succum to starvation or disease if not cror ped by predators.

\section{WHAT HAS ALREADY BEEN DONE FOR THE PROTECTION OF BIRDS OF PREY?}

There has been a marked extensic of legal protection for rapto throughout North America. The fo lowing list indicates that develor ment. Although the situation is $f_{\text {: }}$ from perfect, with only one provinc providing a "model law," it is er couraging to note the recent appea: ance of B.C. in an improved categor and the almost-perfect situation Alberta. 
The phraseology of legislation varies greatly from place to place, and it is impossible to give this in detail here. For example, where the term "model law" occurs, it will indicate that all raptors are protected except where doing specific harm. The definition of "specific harrn" is variable. It is also difficult to state in every case just who is permitted to exercise control. It will mean, however, that all are protected in one way or another, with varying degrees of control in an individual area.

The following is the most recent information available (supplied by John A. Livingston, April, 1958). Birds listed are the raptors which are not protected.

\section{CANADA}

Alberta: Golden Eagle (also provision for an open season on Great Horned Owl, Goshawk, in winter); British Columbia: Goshawk, Cooper's Hawk, Sharp-shinned Hawk, Great Horned Owl, Snowy Owl; Manitoba: Goshawk, Sharp-shinned, Arctic Owl (sic); New Brunswick: no birds protected which are not protected by federal law except certain game species; Newfoundland: Hawks, Great Horned Owl; N.W.T.: no birds protected which are not protected by federal law or local game ordinance; Nova Scotia: Goshawk, Sharp-shinned Hawk, Great Horned Owl; Ontario: model law; P.E.I.: Hawks, Owls's (Eagles and Osprey?); Quebec: Hawks, Owls; Saskatchewan: Snowy Owl, Great Horned Owl, Goshawk, Pigeon Hawk, Duck Hawk, Cooper's Hawk, Sharp-shinned Hawk; Yukon: Golden Eagle, Bald Eagle, all species of hawks and falcons, Great Horned Owl.

\section{UNITED STATES}

In 1955 Ohio and Utah had what amounted to a "model law," and since then California, Florida, Illinois, New York and Rhode Island have enacted model laws, while Maine leaves unprotected only the Great Horned Owl at the moment. Pennsylvania now protects all hawks in the Blue Mountains flyway in autumn, and Virginia passed a new law in April, 1958, details of which are not yet available. Progress is definitely being made!

WHAT IS BEING DONE CURRENTLY?

In British Columbia the Victoria
Natural History Society has a committee which has been assigned the job of preparing a brief to the legislature for the protection of birds.

In Saskatchewan this year, the need for protecting birds of prey will be studied by a special committee of the Regina Natural History Society. Any interested local groups are urged to get in touch with the Regina committee through its convener.

The committee hopes that there will be an active response from many natural history societies, fish and game leagues, $4 \mathrm{H}$ clubs, agricultural associations, etc. Individuals, too, are requested to write in support of the policy of protection, giving specific arguments whenever possible for the desirability of such protection.

The Saskatchewan Natural History Society also hopes to take an active part in this study. All members of the society are asked to give consideration to the bringing in of a resolution at the annual meeting in October asking for blanket protection cf birds of prey. A recommendation to this effect was submitted to the Department of Natural Resources two years ago when the executive learned that a revision of the game laws for the Province of Saskatchewan was under consideration. Following a motion passed at a meeting of the executive on April 23, 1956, a letter was written to the Game Commissioner recommending that the game laws for the province of Saskatchewan include a provision to the effect that All Hawks, Owls, and Eagles be protected except that a farmer or landowner may destroy Hawks or Owls on the land he owns or occupies, which are doing real damage to poultry or other domestic Animals.

No action was taken at the time upon this recommendation, and the Saskatchewan Natural History Society is eager to press for a review of the situation. Members are urged to write to us or to the Regina Natural History Society Birds of Prey Committee, and to be prepared to discuss this topic at the annual meeting on October 18, 1958. At the annual meeting we expect to have John A. Livingston, Executive Director of the Audubon Society of Canada as guest speaker, and we can count on his support and guidance in the submission of a resolution to the government. 